\title{
Unmet need for modern contraception and associated factors among reproductive age group women in Eritrean refugee camps, Tigray, north Ethiopia: a cross-sectional study
}

Kidane Gebrecherkos ${ }^{1}$, Brhane Gebremariam', Abebaw Gebeyehu², Hailay Siyum¹, Gizienesh Kahsay ${ }^{1}$ and Mebrahtu Abay ${ }^{1 *}$ (D)

\begin{abstract}
Objective: Millions of women want to delay or avoid pregnancy, but they are not using contraception, especially in refugee settings. Due to lack of contraception, one fifth of reproductive age group women suffered from unwanted pregnancy and unsafe abortion, which accounted for $78 \%$ of maternal mortality in refugee camps. Therefore, the aim of this study was to assess the prevalence of unmet need for modern contraception and its associated factors among reproductive age group women in Eritrean refugee camps, Tigray, Northern Ethiopia, 2016.

Results: 400 women of reproductive age group interviewed. Prevalence of unmet need for modern contraception in this study was found to be $41.8 \%$ (95\% Cl 36.99\%, 46.63\%). Respondents' unfavorable attitude towards modern contraceptive methods $[\mathrm{AOR}=0.372,95 \% \mathrm{Cl} 0.170,0.818]$ and the availability of modern contraceptive methods $[\mathrm{AOR}=$ $3.501,95 \% \mathrm{Cl} 1.328,9.231]$ were factors significantly associated with unmet need for modern contraception. Respondents' attitude towards modern contraceptive methods and availability of modern contraceptives were independent predictors of unmet need. Governmental and non-governmental organizations should design programs to create behavioral change in women's attitude towards contraceptive use and to secure the availability of contraceptive methods in refugee camp settings.
\end{abstract}

Keywords: Unmet need, Contraceptive use, Reproductive age women, Refugee camp, Tigray, Ethiopia

\section{Introduction}

According to WHO, 2016 report unmet need for contraception is the proportion of currently married or in sexual union women desiring to limit or space childbearing but not using any contraceptive methods. Unmet need remains a useful tool in identifying and targeting women at high risk of unintended pregnancy. It is one of the indicators used for monitoring of family planning programs [1]. The use of modern contraceptive methods remains an important component in the reduction of fertility as

\footnotetext{
*Correspondence: gmebrahtuabay@gmail.com

1 Department of Public Health, College of Health Sciences, Aksum University, Aksum, Ethiopia

Full list of author information is available at the end of the article
}

well as maternal, infant and child morbidity and mortality $[2,3]$.

Many women in crises, be it social crisis like in refugee camps or economic crisis, are vulnerable from the insecurity and disruption of an emergency, they usually face a continuing risk of unwanted pregnancy and various maternal complications. Furthermore, they are at increased risk of sexual violence and its consequences [4]. UNHCR estimates that around 15.4 million bordercrossing refugees found worldwide in 2011. Among those, females and children accounted for $48 \%$ and $46 \%$ of the total refugees respectively [4]. Ethiopia was the sixth largest country with regard to number of refugee population having a total of 376,400 refugees by the end of 2012 [5]. women and children in refugee camps may 
actually increase their risk of being sexually violated, and are exposed to rape, unintended pregnancy, unsafe abortions and spread of STI /HIV which lead them to longterm psychological problem and high infant \& maternal mortality $[6,7]$.

According to UNHCR, 2015 health information system (HIS) annual report, the utilization of modern contraceptive methods among Eritrean women, reside in refugee camps of Tigray, Ethiopia is low (32\%) [8]. Complications during pregnancy or childbirth are the leading causes of death and disability among women of reproductive age group in developing countries. This is even worse in areas where there is conflict as it leads to lack of accessibility to family planning [9].

Refugee women in conflict situations are at an increased risk for unintended pregnancies, poor child spacing, unfavorable pregnancy outcomes and STIs including HIV [10]. The higher rate of unmet need is worse among refugees in Sub-Saharan Africa. Rural residents, un-educated and poor women are also at higher risk [11-13].

Displaced women expose to sexual violence, sexual exploitation and abuse, which all lead to different health related complications [14, 15]. Over all, lack of contraception leads to impediments in health, human rights, social and economic development. These conditions indicate that reproductive health care is crucial need of refugees, from comprehensive family planning support to emergency contraception provision [16-18].

As there is no previous study in the study area, this study aims at assessing the prevalence and predictors of unmet need for modern contraception among the reproductive age group women of Eritrean refugee's in Tigray, north Ethiopia.

\section{Main text \\ Methods \\ Study setting, study population and sampling}

Community based cross-sectional study was conducted among women of reproductive age group in Eritrean refugees found in Tigray, Ethiopia from July to September 2016. There are four Eritrean refugee camps in shire operation named as "Adi-harush", "Shimelba", "Mayayni" and "Hitsats", which are located 1167, 1203, 1150, and 1120 Kilometers far from Addis Ababa, the capital of Ethiopia. According to UNHCR 2016 population report, there were 6680 reproductive age group women refugees in the camps. After we obtained a list of each household from the respective refugee, reproductive age group women were selected proportional from each refugee camp. Finally, systematic random sampling method was used to get respondents. Sample size was determined using a single population proportion formula with the assumptions prevalence of unmet need $(\mathrm{p}=0.5$, because there was no previous study), $\left.95 \% \mathrm{CI}\left(\mathbf{Z}_{1-\alpha / 2}\right)=1.96\right), 5 \%$ degree of marginal error (d), finite population correction formula (because the total women in the refugee camps were $<10,000)$ and $10 \%$ non-response rate. The sample size was 400 [19].

\section{Data collection and data quality control}

Data were collected using structured interview administered questionnaire, which was adapted and modified from (EDHS), 2011 [20]. The questionnaire was pretested by the principal investigators in "Endabaguna" Town, Tigray, and north Ethiopia.

Data were collected by interviewing the respondents. Eight diploma nurses collected the data and supervised by four BSc nurses. To assure quality of the data, training was given to the data collectors and supervisors by the principal investigator for 2 days. The supervisors and principal investigator checked the filled questionnaires daily. During data collection, if there were more than eligible women in a household one woman selected randomly.

\section{Variables and measurement}

Dependent variable Unmet need for modern contraception (unmet versus met need).

Independent variables Socio-demographic, reproductive, contraceptive related and service provision related variables.

Favorable attitude towards modern contraceptive methods Respondents who scored points greater than or equal to the mean score (45.2) of the total 12 items of attitude related questions.

Knowledgeable about modern contraceptive methods When a women is able to mention at least one modern contraceptive methods by here self or know after description of any modern method.

Unmet need for modern contraception Refers to the contraceptive need of fecund and currently married women or women in union who are either not pregnant and want child later on or not at all, or who are pregnant as result of a miss-timed or unwanted pregnancy but not using any contraceptive method.

Unmet need for limiting The percentage of non-pregnant women who do not want another child at all and are pregnant because of unwanted pregnancy, but not using any modern contraceptive method.

Unmet need for spacing The percentage of not pregnant women who want another child after 2 years and are pregnant as result of a miss-timed pregnancy, but not using any modern contraceptive method. 


\section{Data management and analysis procedure}

We coded, cleaned and entered the collected data by using SPSS version 21.0 and analyzed. Descriptive statistics like mean and standard deviation were used to quantitative data, and frequencies and proportions used for categorical data. Binary logistic regression analysis using odds ratios (ORs), 95\% confidence intervals (CIs) were used to determine association between predictors and the outcome variable. Variables with the P-value of less than 0.05 in both the bivariable and multivariable logistic regression models were considered as statistically significant predictors.

\section{Results}

A total of 400 participants were included in the study having a $100 \%$ response rate.

\section{Socio-demographic characteristics}

Data from 400 reproductive age group women were analyzed. The mean $( \pm S D)$ age of the women was $28.39( \pm 7.15)$. Related to the marital status and residency, 314 (78.5\%) were married and 238 (59.5\%) reside in rural areas before displaced from their country. Regarding ethnicity, 245 (61.3\%) were Tigrigna. A little above half (54\%) of the total respondents were attended elementary school and were Orthodox Christian (55.5\%) by religion. More than two-third $(69.3 \%)$ of the respondents were housewives by occupation before displacing. Three hundred forty five (86.3\%) of partners/husbands of the women had attained formal education, and 315(78.8\%) of them had occupation (Table 1).

\section{Reproductive health characteristics}

The mean $( \pm \mathrm{SD})$ age at first marriage was $19( \pm 2.6)$ years old. Three hundred forty-three $(85.8 \%)$ women had history of pregnancy, among those 349 (87.4\%) had more than one pregnancy in their lifetime. A hundred and sixty-seven (41.8\%), women had unmet need for modern contraception in the study. Three hundred sixteen (79\%) respondents have ever heard about modern contraceptive methods. Out of those, 157 (39.25\%) participants had knowledge and 235 (58.75\%) had favorable attitude towards use of modern contraceptive methods. Two hundred forty-five (61.5\%) of the women had discussed with their husband on modern contraceptive methods use and $182(45.5 \%)$ of the respondents were supported to use contraceptive methods by their husbands. Both partners decided to use modern contraceptive methods was 203 $(50.8 \%)$ and decided on the number of children to have for the future in their life together 291 (72.8\%). Two hundred eight (52\%) of the respondents had history of exposure to media about modern contraceptive methods and 192 (48\%) had not (Table 2).

\section{Prevalence and factors associated with unmet need for modern contraceptive methods}

The total unmet need for modern contraception was $41.8 \%$ (95\% CI 36.99\%-46.63\%) with $31.8 \%$ unmet need for spacing and $10 \%$ unmet need for and limiting. The analysis of bivariable logistic regression indicated that history of abortion, ever use of modern contraceptive methods, number of ANC visits and exposure to media about modern contraceptives were variables significantly associated with modern contraception. In addition, attitude towards modern contraceptives, discussion with husband on contraception, availability of modern contraceptive methods in the health facility, and discussion on contraception with community health workers were significant variables associated with unmet need for modern contraception with p-value $<0.05$.

In the multivariable logistic regression model, respondents' attitude towards modern contraceptive use and availability of modern contraceptive methods were significantly associated with the unmet need for modern contraceptive use. Women who had no enough availability of modern contraceptive methods were 3.5 times more likely to have unmet need for modern contraception as compared to those who have [AOR $=2.7795 \%$ CI (1.63, 4.70)]. Women who had favorable attitude towards utilization of modern contraceptive methods were less likely to have unmet need for modern contraception by $63 \%$ as compared to those who had unfavorable attitude $[\mathrm{AOR}=$ 0.49 95\% CI $(0.31,0.79)]$ (Table 3).

\section{Discussion}

The overall prevalence of unmet need for modern contraception was $41.8 \%$ (95\% CI: $36.99 \%-46.63 \%)$. This is higher than studies conducted in Djibouti (8.8\%), Kenya (9.9\%), Uganda (7.8\%) and Canada [21-24]. Whereas, it is lower than a study conducted in Uganda (52.1\%) [25]. The discrepancy might be due to differences in expanded health service provision, availability and awareness to contraceptive methods, socio economic status, and educational status.

In multivariable analysis, respondents' attitude towards modern contraceptive methods and availability of modern contraceptive methods found to be significant and determinant factor for the unmet need.

Women who had no enough availability of modern contraceptive methods were more likely to have unmet need as compared to those who have [AOR $=2.77,95 \%$ CI $(\mathbf{1 . 6 3}, \mathbf{4 . 7 0})]$. This is consistent with the multi-country baseline assessment done among women selected refugee settings [26]. This result also supported with studies conducted among refugee women in Nigeria and Pakistan $[27,28]$. Those studies suggested that there was a lack of availability to use modern contraceptive methods; none 
Table 1 Socio-demographic characteristics of reproductive age group (15-49) women in Eritrean refugee camps in Tigray, north Ethiopia, 2016

\begin{tabular}{|c|c|c|c|}
\hline Variables & Category & Number (n) & Percent (\%) \\
\hline \multirow{5}{*}{$\begin{array}{l}\text { Age of women (in } \\
\text { years) }\end{array}$} & $15-19$ & 41 & 10.25 \\
\hline & $20-24$ & 84 & 21.00 \\
\hline & $25-29$ & 113 & 28.25 \\
\hline & $30-34$ & 83 & 20.75 \\
\hline & 35 and above & 79 & 19.75 \\
\hline \multirow[t]{4}{*}{ Religion } & Orthodox & 222 & 55.50 \\
\hline & Muslim & 84 & 21.00 \\
\hline & Protestants & 38 & 9.50 \\
\hline & Catholic & 56 & 14.00 \\
\hline \multirow[t]{3}{*}{ Ethnicity } & Tigrigna & 245 & 61.25 \\
\hline & Saho & 83 & 20.75 \\
\hline & Kunama & 72 & 18.00 \\
\hline \multirow[t]{4}{*}{ Marital status } & Married & 314 & 78.50 \\
\hline & Single & 26 & 6.50 \\
\hline & Divorced & 36 & 9.00 \\
\hline & Widowed & 24 & 6.00 \\
\hline \multirow[t]{4}{*}{ Educational status } & Illiterate & 78 & 19.50 \\
\hline & $\begin{array}{l}\text { Elementary school } \\
\quad(1-8 \text { th) }\end{array}$ & 216 & 54.00 \\
\hline & Secondary school & 93 & 23.25 \\
\hline & Higher education & 13 & 3.25 \\
\hline \multirow[t]{3}{*}{ Occupational status } & House wife & 277 & 69.25 \\
\hline & Daily laborer & 82 & 20.50 \\
\hline & Student & 41 & 10.25 \\
\hline \multirow{4}{*}{ Husband's religion } & Orthodox & 240 & 60.00 \\
\hline & Muslim & 74 & 18.50 \\
\hline & Protestant & 30 & 7.50 \\
\hline & Catholic & 56 & 14,00 \\
\hline \multirow{4}{*}{$\begin{array}{l}\text { Monthly household } \\
\text { income (in Eriterian } \\
\text { Nakfa) }\end{array}$} & $<400$ & 45 & 11.25 \\
\hline & $401-745$ & 64 & 16.00 \\
\hline & $746-1220$ & 113 & 28.25 \\
\hline & $>1220$ & 178 & 44.50 \\
\hline
\end{tabular}

of the clients was using long and permanent modern contraceptive methods. At the same time, female condom utilization was nearly zero, emergency contraception was only available in the situation of post rape care; only short-term contraceptive methods reported. This causes low utilization of modern contraceptive services in the refugee settings.

Respondents' attitude towards modern contraceptive use has a relevant input to meet the unmet need. Women who had favorable attitude towards utilization of modern contraceptive methods were less likely to have unmet need as compared to those who had unfavorable attitude $[\mathrm{AOR}=0.49,95 \% \mathrm{CI}(0.31,0.79]$. This finding was supported by a research conducted among refugees in
Table 2 Reproductive health characteristics of reproductive age group women in Eritrean refugee camps in Tigray, north Ethiopia, 2016

\begin{tabular}{|c|c|c|c|}
\hline Variables & Category & Number (n) & Percent (\%) \\
\hline \multirow{2}{*}{$\begin{array}{l}\text { Age at first } \\
\text { marriage(in years) }\end{array}$} & $<18$ & 176 & 47.10 \\
\hline & $\geq 18$ & 198 & 52.90 \\
\hline \multirow[t]{2}{*}{ History of abortion } & No & 279 & 74.60 \\
\hline & Yes & 95 & 25.40 \\
\hline \multirow{4}{*}{$\begin{array}{l}\text { Desired number of } \\
\text { children }\end{array}$} & $\leq 5$ & 179 & 47.86 \\
\hline & $>5$ & 71 & 18.98 \\
\hline & $\begin{array}{l}\text { Don't want more } \\
\text { child }\end{array}$ & 64 & 17.11 \\
\hline & Undecided & 60 & 16.04 \\
\hline \multirow{2}{*}{$\begin{array}{l}\text { Ever use of modern } \\
\text { contraceptive } \\
\text { methods }\end{array}$} & No & 203 & 50.75 \\
\hline & Yes & 197 & 49.25 \\
\hline \multirow{2}{*}{$\begin{array}{l}\text { Current use of mod- } \\
\text { ern contraceptive } \\
\text { methods }\end{array}$} & No & 296 & 74.00 \\
\hline & Yes & 104 & 26.0 \\
\hline \multirow{4}{*}{$\begin{array}{l}\text { Types of modern } \\
\text { contraceptive } \\
\text { methods currently } \\
\text { used }\end{array}$} & Oral pill & 31 & 29.81 \\
\hline & Injectable & 52 & 50.00 \\
\hline & Implant & 15 & 14.42 \\
\hline & IUCD & 4 & 3.85 \\
\hline \multirow{2}{*}{$\begin{array}{l}\text { Current pregnancy } \\
\text { status among non- } \\
\text { users }\end{array}$} & Non-pregnant & 187 & 63.18 \\
\hline & Pregnant & 109 & 36.82 \\
\hline \multirow[t]{3}{*}{ Type of pregnancy } & Wanted now & 63 & 57.80 \\
\hline & Unwanted & 11 & 10.09 \\
\hline & Mistimed & 35 & 32.11 \\
\hline \multirow{2}{*}{$\begin{array}{l}\text { Current amenorrhea } \\
\text { among non-users }\end{array}$} & Not amenorrheic & 197 & 66.55 \\
\hline & Amenorrheic & 99 & 33.45 \\
\hline \multirow[t]{4}{*}{$\begin{array}{l}\text { Reason for not being } \\
\text { pregnant }\end{array}$} & $\begin{array}{l}\text { Wanted child later } \\
\text { on }\end{array}$ & 92 & 49.20 \\
\hline & No more want child & 29 & 15.50 \\
\hline & Want child soon & 54 & 28.88 \\
\hline & In fecund & 12 & 6.42 \\
\hline \multirow{2}{*}{$\begin{array}{l}\text { Anti natal care (ANC) } \\
\text { visit }\end{array}$} & No & 13 & 11.93 \\
\hline & Yes & 96 & 88.07 \\
\hline \multirow{2}{*}{$\begin{array}{l}\text { Age started using } \\
\text { modern contra- } \\
\text { ception methods }\end{array}$} & $15-19$ & 42 & 21.30 \\
\hline & $20-24$ & 107 & 54.30 \\
\hline $\begin{array}{l}\text { Respondent's } \\
\text { knowledge about } \\
\text { modern contra- } \\
\text { ceptives }\end{array}$ & $\geq 25$ & 48 & 24.4 \\
\hline \multirow{4}{*}{$\begin{array}{l}\text { Respondent's } \\
\text { attitude towards } \\
\text { modern contra- } \\
\text { ceptive use }\end{array}$} & Knowledgeable & 157 & 39.25 \\
\hline & Not knowledgeable & 243 & 60.75 \\
\hline & Favorable attitude & 235 & 58.75 \\
\hline & Unfavorable attitude & 165 & 41.25 \\
\hline
\end{tabular}

Ethiopia [19]. The possible explanation could be women having unfavorable attitude towards modern contraceptive use influence the utilization of the services. 
Table 3 Factors associated with unmet need for modern contraception methods among reproductive age women in Eritrean refugee camps, Tigray, north Ethiopia, 2016

\begin{tabular}{|c|c|c|c|c|c|}
\hline \multirow[t]{3}{*}{ Variables } & \multirow[t]{3}{*}{ Category } & \multicolumn{2}{|l|}{ Unmet need } & \multirow[t]{3}{*}{ COR $(95 \% \mathrm{Cl})$} & \multirow[t]{3}{*}{ AOR $(95 \% \mathrm{Cl})$} \\
\hline & & Yes & No & & \\
\hline & & Number (\%) & Number (\%) & & \\
\hline \multirow{2}{*}{$\begin{array}{l}\text { Attitude towards contra- } \\
\text { ceptive use }\end{array}$} & Favorable & 72 (30.6) & $163(69.4)$ & $0.33(0.22,0.49)^{*}$ & $0.49(0.31,0.79)^{* *}$ \\
\hline & Unfavorable & 95 (57.6) & $70(42.4)$ & 1.00 & 1.00 \\
\hline \multirow{2}{*}{$\begin{array}{l}\text { Availability of modern } \\
\text { contraceptive methods }\end{array}$} & Yes & $98(33.1)$ & $198(66.9)$ & 1.00 & 1.00 \\
\hline & No & $69(66.3)$ & 35 (33.7) & $3.98(2.48,6.39)^{*}$ & $2.77(1.63,4.70)^{* *}$ \\
\hline
\end{tabular}

* Significant in the bivariable logistic regression at $p$-value $<0.05$

** Significant in the multiple logistic regression at $p$-value $<0.05$

\section{Conclusion}

The prevalence of unmet need for modern contraceptive methods in the study area was $41.8 \%$. Women attitude towards modern contraceptive methods and availability of modern contraceptive methods were significantly and independently predictors of unmet need for modern contraception.

Different stakeholders, together with Ethiopian government, should take a commitment to strengthen the availability of modern contraceptive supplies in the Eritrean refugee camps. They should also develop, together with health professionals, implementing programs to bring behavioral change and favorable attitude towards modern contraceptive use among Eritrean women in the refugee camps.

\section{Limitation}

The study used self-report (using questionnaire) method to measure the different independent variables, which may sometimes result in biased result.

\footnotetext{
Abbreviations

ARRA: administrative for refugees and returnee affairs; CSA: Central Statistical Agency; DHS: Demographic Health Survey; CPR: contraceptive prevalence rate; EDHS: Ethiopian Demographic Health Survey; FMOH: Federal Ministry of Health; FP: family planning; HIV: human immune deficiency virus; IDP. internally displaced persons; IRC: International Rescue Committee; NGO: NonGovernmental Organization; PI: principal investigator; SPSS: Statistical Package for the Social Sciences; STI: sexual transmitted infections; WHO: World Health Organization; UN: United Nations; USAID: United States Agency for International Development; UNFPA: United Nations Fund for Population Activities; UNHCR: United Nations Higher Commissioner for Refugees.
}

\section{Authors' contributions}

KG and BG: Developed the proposal, analyzed data, and wrote the report and the manuscript. AG: Organized the overall process. GK, MA and HS: Contributed in proposal writing, data collection and analysis. All authors read and approved the final manuscript.

\section{Author details}

${ }^{1}$ Department of Public Health, College of Health Sciences, Aksum University, Aksum, Ethiopia. ${ }^{2}$ Institute of Public Health, College of Health Sciences, University of Gondar, Gondar, Ethiopia.

\section{Acknowledgements}

We would like to acknowledge the Administration of Refugee and Returnee Affair (ARRA) staff for their kind support and permission in getting references and data about the population's profile. We are also grateful to Department of Public Health, College of Health Sciences, Aksum University, Aksum, Ethiopia for giving us this opportunity to do this research.

\section{Competing interests}

The authors declare that they have no competing interests.

\section{Availability of data and materials}

The minimal anonymized pertinent data is with the manuscript. The metadata was already submitted to dryad online data depository and is available at the following URL: http://datadryad.org/review?doi=doi:10.5061/dryad.1js13 9d.

\section{Consent for publication}

Not applicable, no individual detail presented.

\section{Ethical approval and consent to participate}

We obtained Ethical clearance from ethical review Board of Aksum University College of Health Sciences and Letter of Permission from each camp. During data collection, written informed consent was also obtained from study participants after the purpose of the study was explained. Anonymity and confidentiality of the collected data kept.

\section{Funding}

There was no specific funding received for this study.

\section{Publisher's Note}

Springer Nature remains neutral with regard to jurisdictional claims in published maps and institutional affiliations.

Received: 9 September 2018 Accepted: 26 November 2018

Published online: 04 December 2018

\section{References}

1. WHO. Unmet need for family planing. Human reproduction program. Geneva: World Health Organization; 2016.

2. Daniels K, et al. Current contraceptive use and variation by selected characteristics among women aged 15--44: United States, 2011-2013. Natl Health Stat Report. 2015;86:1-14.

3. Chibuye N. Family structure and modern contraceptive use among women in Malawi, 2016. 
4. Curry DW, et al. Delivering high-quality family planning services in crisis-affected settings I: program implementation. Global Health. 2015;3(1):14-24.

5. Farzaneh N, et al. Displacement: the new 21st century challenge. UNHCR global trends 2012. Forced Migr Rev. 2011;2(38):16-7.

6. Senanayake P, Potts M. Atlas of contraception. New York: CRC Press; 2008.

7. McGinn T, et al. Family planning in conflict: results of cross-sectional baseline surveys in three African countries. Conflict Health. 2011;5(1):1.

8. UNHCR, Contraceptive prevalence rate among reproductive age women in Eritrean refugees, Tigray, Ethiopia. Health Information systems (HIS). 2015.

9. Deyo NS. Cultural traditions and the reproductive health of Somali refugees and immigrants. 2012

10. Sonneveldt E, Shaver T, Bhuyan A. Understanding operational barriers to family planning services in conflict-affected countries: experiences from Sierra Leone. 2008.

11. Sheila Dunn PJ. Jennifer Blake, Susan Hum, Marianne Cheetham, Vivian Welch, Kevin Pottie; for the Canadian Collaboration for Immigrant and Refugee Health, Contraception: evidence review for newly arriving immigrants and refugees. 2011

12. Hynes $\mathrm{M}$, et al. A study of refugee maternal mortality in 10 countries, 2008-2010. Int Persp Sex Reprod Health. 2012;38:205-13.

13. York S. The reproductive rights of refugees. 2012. http://www.howma ny.org.

14. Feseha G, Gerbaba M. Intimate partner physical violence among women in Shimelba refugee camp, northern Ethiopia. BMC Public Health. 2012:12(1):125

15. Arrault M, Miquel J. GBV assessment kebri beyah and Shimelba refugee CAMP. UNFPA; 2007: p. 5-23.

16. Spiegel PB. HIV/AIDS among conflict affected and displaced populations: dispelling myths and taking action. Disasters. 2004;28(3):322-39.

17. Munyewende $P$, et al. Exploring perceptions of HIV risk and health service access among Zimbabwean migrant women in Johannesburg: a gap in health policy in South Africa? J Public Health Policy. 2011;32(1):S152-61.
18. Chen MI, et al. Reproductive health for refugees by refugees in Guinea II: sexually transmitted infections. Conflict Health. 2008;2(1):14.

19. Gashawbeza H. Levels and determinants of fertility among refugees in Ethiopia, 2014.

20. ICF, C.S.A. Ethiopia Demographic and Health Survey, 2011. Addis Ababa, Ethiopia and Calverton, Maryland, USA: Central Statistical Agency and ICF International. 2012.

21. Farzaneh N. Baseline study: Documenting knowledge attitudes and behaviours of Somali refugees and the status of family planning services in UNHCRs Ali Addeh site Djibouti. 2015.

22. Mankani N. Baseline study: documenting knowledge attitudes and practices of refugees and the status of family planning services in UNHCRs operations in Nakivale Refugee Settlement Uganda. 2011.

23. McCoy E. Baseline study: Documenting knowledge attitudes and behaviours of Somali refugees and the status of family planning services in UNHCRs operation in Nairobi Kenya. 2011.

24. Casey SE, et al. Availability of long-acting and permanent family-planning methods leads to increase in use in conflict-affected northern Uganda: evidence from cross-sectional baseline and endline cluster surveys. Global Public Health. 2013:8(3):284-97.

25. Aptekman $M$, et al. Unmet contraceptive needs among refugees crossroads clinic experience. Can Fam Physician. 2014;60(12):e613-9.

26. Krause, S. Refocusing family planning in refugee settings: Findings and recommendations from a multi-country baseline study with a brief film. In: 141st APHA Annual Meeting and Exposition (November 2-November 6, 2013). APHA; 2013.

27. Okanlawon K, Agbaje OF, Reeves M. Contraceptive use: knowledge, perceptions and attitudes of refugee youths in Oru Refugee Camp, Nigeria: original research article. Afr J Reprod Health. 2010;14(4):17-26.

28. Raheel $\mathrm{H}$, et al. Knowledge, attitudes and practices of contraception among Afghan refugee women in Pakistan: a cross-sectional study. PLoS ONE. 2012;7(11):e48760.
Ready to submit your research? Choose BMC and benefit from:

- fast, convenient online submission

- thorough peer review by experienced researchers in your field

- rapid publication on acceptance

- support for research data, including large and complex data types

- gold Open Access which fosters wider collaboration and increased citations

- maximum visibility for your research: over 100M website views per year

At $\mathrm{BMC}$, research is always in progress.

Learn more biomedcentral.com/submissions 